〈論文〉

生物学的脱リン過程の二相生物モデルによるシミュレーション

尹 照 熙* 鈴 木 基 之*

\title{
Simulation by Using Model of Two Species of Biomass on Biological Phosphorus Removal Processes
}

\author{
Cho-Hee YOON* and Motoyuki SUZUKI*
}

* Institute of Industrial Science, University of Tokyo, Roppongi 7-22-1, Minato-ku, Tokyo 106 Japan

\begin{abstract}
A simulation model for changes of phosphorus and organic carbon concentration in a cycle period on biological phosphorus removal is developed in this study.

We propose a model based on a simple combination of two species of biomass, based on its phosphorus content. Changes of phosphorus and organic carbon concentrations under anaerobic/aerobic condition are simulated and estimated for the effects of organic carbon loading, the ratio of phosphorus accumulating biomass to total biomass, biomass concentration and the maximum specific growth rate.

Phosphorus release/uptake in the biomass during a cycle period could basically be attained by controlling of orgaic carbon concentration and the ratio of phosphorus accumulating biomass to total biomass.

The prediction of profiles of phosphorus and organic carbon concentrations in the reactor gives fair agreement with the experiment results.
\end{abstract}

Key words : simulation model, phosphorus release/uptake, two species of biomass, anaerobic/aerobic condition

\section{1. 緒言}

生物学的脱リンプロセスでは, 現在一般的に嫌気・ 好気状態の繰り返しによる脱りンプロセスが主流と なっている。しかしながら，この脱リンプロセスは実 際の操作上では負荷変動に対して不安定であることが 指摘されて扣り，そのために多くの研究者が生物学的 脱リンの機構解明を研究の対象としてきた ${ }^{1 \sim 3)}$ 。その過 程で, 微生物中のポリリン酸の役割の重要性が認識さ れて以来, NMR 法(4), STS 法5)などを用いた微生物内 のリン挙動の分析が行われている。これらに基づいて Arun $ら^{6)}$ や Komeau $ら^{7)}$ は ADP/ATP, NAD/NAD,
$\mathrm{NAD} / \mathrm{NADH}$ 㧊よびプロトン移動力 (proton motive force；pmf）の概念を導入した生化学的な反応モデル の提案を試みた。しかし, これらのモデルは微生物中 でのリンおよび有機質の挙動についての定性的, かつ 素反応的な解明であり，また実際の定量的な測定には 誤差がつきまとうことなどの難点もあり, 実際のシス テムにこの考光方を応用することは難しい。このよう な実際との対応が難しいモデルを用いる検討よりも， システム全体でのリン执よび有機物の変化の現象が推 定でき，現象に最も影響を与える因子が何であるかを 説明できるモデルが実際には必要となろう。これまで のところ, 槽内のリン濃度の変化の推定に関する研究

* 東京大学生産技術研究所 $=106$ 東京都港区六本木 7-22-1 
はそれほど多くないが, その中の代表的な研究として, Tsuno ら $^{8}$ は槽内の有機物成分を考慮した速度式を導 きリン捛よび有機物の挙動について検討している。 しかし, 彼らの研究では微生物体内の有機物の各成分 の反応経路を定量的に検討することが困難であること が問題とある。

そこで, 本研究は以上の様な関題点を解決し, シス テム全体でのリンの放出・摄取拈よび有機物の変化の 現象を推定することを目的として, 現象の簡単なモデ ル化を行い, 環境変化に伴らリンの放出・摂取の現象 についての解析を行い, 実験值と比較検討した。

\section{2. 槽内のリンおょび有機物の挙動特性}

\section{1 モデルの概念}

嫌気・好気法による生物学的脱リンサイクルに打い ては, 嫌気状態で槽内の有機物の減少に伴ら液中のリ ンの増加が生じ, 好気状態で微生物によるリンの過劋 摂取現象が生じる。これまでの報告例では，この挙動 は活性污泥（微生物）によって一見まちまちの挙動を とっているよらに見光たが，ここでは槽内の微生物を 二つに大別して,リンを効率よく蓄積しらる微生物(以 下脱リン性微生物（略字p）と呼ぶ）之，その能力を有 しない微生物 (以下非脱りン性微生物 (略字 $n$ )) の二相 で構成されるとし, 脱リン性微生物の全微生物中の存 在割合 (f) は各段階に括ける全微生物のリンの含有率 $\left(P_{X}\right)$ と一義的に対応すると仮定した。

脱リン性微生物の代謝経路としては, 嫌気状態での リンの放出抢よび有機物の摂取・蓄積と, 好気状態で のリンの摂取拉よび有機物の摄取, また蓄積有機物の 分解などが重要であり, それらに伴う増殖打よび死隇 を考慮する必要がある。また，非脱りン性微生物の代 謝経路については, 嫌気状態での有機物の摂取・蓄積・ 分解と, 好気状態でのリンの摂取执よび有機物の摂取, 蓄積有機物の分解などが重要であり，それに伴って増 殖拉よび死隇が生じる。

この両者の競合関係によってリン，有機物の液中濃 度変化が記述される。システム内の二相微生物につい ての嫌気・好気状態での主な代謝経路のモデルの概念 図をFig. 1 に示した。

Fig.1 の左側に示したように，嫌気状態における脱 リン性微生物のリンの放出は, 有機物の摂取と生命体 の内生的な維持のためのエネルギー源としてポリリン 酸9)の加水分解による放出である。その時, 有機物が摂 取され, glycogen ${ }^{10)}, \mathrm{PHB}^{7)}$ ような有機物として微生物 体内に貯蔵される。好気状態では Fig. 1 の右側に示し たようにリンを摄取し，摂取したリンは微生物体内に ポリリン酸として蓄積され,一部は増殖に利用される。
その際に，嫌気状態で貯蔵した有機物が利用される。 一方, 非脱リン性微生物の場合, 嫌気状態で有機物 を摂取して体内に蓄積し，生命体の内生的な維持のた めのエネルギー源としてそれを利用する。リンの摂取 は好気状態の増殖に伴うもののみである。

以上の現象について簡単な基礎式を立てるために, 次のような仮定をもらける。

1) 槽内は完全混合槽であり, 繰り返しサイクルは動 的定常状態にある。

2）リンの放出には脱リン性微生物のみが関与する。

3) 脱リン性微生物の最大可能リン含有率は 0.15 $\mathrm{kgP} \cdot \mathrm{kgMLSS}^{-1}$ とする。

4 ) 微生物は好気状態で増殖する。

5 ）好気状態での微生物の増殖制限基質は, 体内の蓄 積有機物と液中のリンである。

\section{2 リンの挙動特性の定式化}

\section{2 .1 嫌気状態でのリンの放出速度}

嫌気状態に扣ける回分式反応槽での単位体積当りの リンの物質収支式として次式が得られる。

$\mathrm{d} P / \mathrm{d} t=-\mathrm{d}\left(X \cdot P_{X}\right) \mathrm{d} t$

ここで, 微生物からのリン放出については脱リン性 微生物のみが関与し, 全微生物の濃度（脱リン性微生 物十非脱リン性微生物: $\left.X=X_{p}+X_{n}\right)$ 抢よび $P_{X_{n}}$ を 一定とすると, 式(1)は次式に書ける。

$$
\mathrm{d} P / \mathrm{d} t=-X_{p} \cdot \mathrm{d} P_{X_{n}} / \mathrm{d} t
$$

ただし, $P$ は液中のリンの濃度, $X$ は全微生物の濃度, $P_{X}$ は全微生物の単位重量当りの平均含有率, $X_{p}$ は脱 リン性微生物の濃度, $X_{n}$ は非脱リン性微生物の濃度,

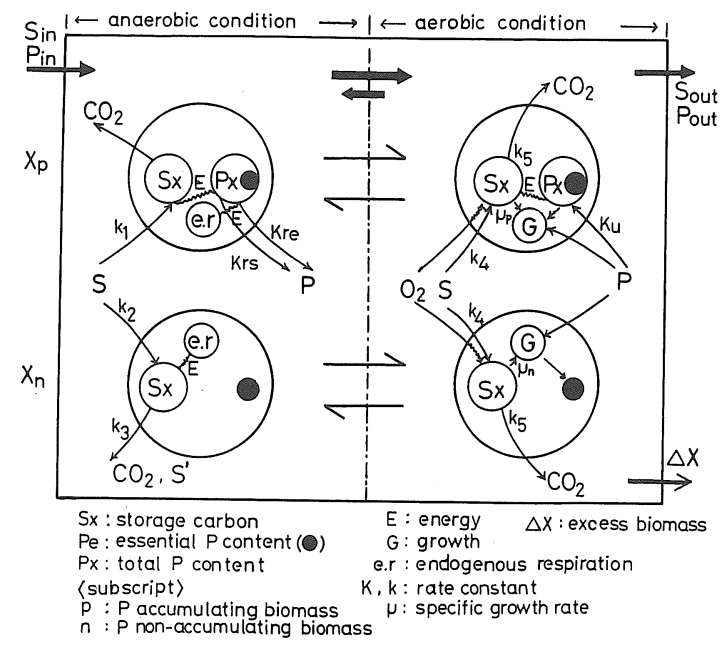

Fig. 1 Illustration of model concept in two species biomass under cyclic anaerobic/aerobic condition. 
$P_{X_{p}}$ は脱リン性微生物の単位重量当りのリンの含有 率, $P_{X n}$ は非脱リン性微生物の単位重量当りのリンの 含有率である。

脱リン性微生物からのリンの放出速度は, 有機物の 摂取に伴う放出速度と生命体の内生的な維持によるリ ンの放出速度の和であると考学る。

$$
\mathrm{d} P_{X p} / \mathrm{d} t=\left(\mathrm{d} P_{X p} / \mathrm{d} t\right)_{1}+\left(\mathrm{d} P_{X p} / \mathrm{d} t\right)_{2}
$$

有機物の摂取に伴らリンの放出速度は, 微生物中のリ ンの含有率に 1 次で比例すると考光られ ${ }^{8)}$, 式(3)の右 辺の第 1 項は次式で表される。

$$
\left(\mathrm{d} P_{X p} / \mathrm{d} t\right)_{1}=-K_{r s} \cdot P_{X p}
$$

ここで, リンの放出速度定教 $\left(K_{r s}\right)$ は摂取可能な有 機物濃度 $\left(S-S_{a}\right)$ (ただし, $S$ は全有機物の濃度, $S_{a}$ は嫌気状態で微生物が摂取不可能な有機物の濃度）の 関数であり, Monod 型の次式が得られる ${ }^{11)}$ 。

$$
K_{r s}=K_{r s m} \cdot\left(S-S_{a}\right) /\left\{K_{S}+\left(S-S_{a}\right)\right\}
$$

ただし， $K_{r s m}$ は $\left(S-S_{a}\right)$ の制限がない場合のリンの放 出速度定数である。

また，生命体の内生的な維持によるリンの放出速度 は，放出可能なリンの含有率に基づき Monod 型に従 らと仮定し, 式(3)の右辺の第 2 項は次式で表される。

$$
\begin{aligned}
\left(\mathrm{d} P_{X p} / \mathrm{d} t\right)_{2}= & -K_{r e} \cdot\left(P_{X_{p}}-P_{e_{p}}\right) \\
& /\left\{K_{p X}+\left(P_{X_{p}}-P_{e_{p}}\right)\right\}
\end{aligned}
$$

ただし, $K_{r e}$ はリンの放出速度定数であり, $K_{p X}$ は飽和 定数である。 $P_{e_{p}}$ は微生物の必須リン含有率であり, 本 研究では $P_{e_{p}}$ の值として $0.02 \mathrm{~kg} \cdot \mathrm{kg}^{-1}$ を設定する ${ }^{12)}$ 。

式(2)に式(3) (6)を代入し, 初期条件を与充て解を求 めると, 嫌気状態に执ける槽内执よび微生物でのリン の挙動が推定でさる。

嫌気状態の初期の脱リン性微生物のリンの含有率を $P_{X P m}$, 槽内のリンの濃度を $P_{0}$ とすると初期条件として

$$
t=0, \quad P_{X_{p}}=P_{X_{p m}}, \quad P=P_{0}
$$

が与方れる。

\section{2 .2 好気状態でのリンの摄取速度}

好気状態に执いては微生物の増殖が生じるため, 回 分式反応槽で単位体積液当りのリンの物質収支式とし ては次式が得られる。

$$
-\mathrm{d} P / \mathrm{d} t=\mathrm{d}\left(X \cdot P_{X}\right)_{p} / \mathrm{d} t+\mathrm{d}\left(X \cdot P_{X}\right)_{n} / \mathrm{d} t
$$

式(8)の右辺の第 1 項は脱リン性微生物によるリンの 変化速度の項であり, 第 2 項は非脱リン性微生物によ るリンの変化速度の項である。すなわち，槽内のリン 濃度の減少速度は, 脱リン性微生物による体内へのリ ンの蓄積执よび増殖に伴らリンの摂取速度と, 非脱り ン性微生物の増殖に伴らリンの摂取速度の和である。 これらの事実に基づき,式(8)は次式に書き改められる。

$$
\begin{aligned}
-\mathrm{d} P / \mathrm{d} t= & X_{p} \cdot \mathrm{d} P_{X_{p}} / \mathrm{d} t+P_{X_{p}} \cdot \mathrm{d} X_{P} / \mathrm{d} t \\
& +P_{X_{n}} \cdot \mathrm{d} X_{n} / \mathrm{d} t
\end{aligned}
$$

ここで， $P_{X n}$ は非脱リン性微生物のリンの含有率であ り，脱リン性微生物の必須リン含有率 $\left(P_{e_{p}}\right)$ と同様の 值であると考劣ることとする。

脱リン性微生物に扣けるリンの過剒摂取速度の推進 力は体内に最大で含有できるリン量とその時に体内に 含有しているリン量の差であると仮定し, 式(9)の右辺 の第 1 項と $\mathrm{d} P_{X_{p}} / \mathrm{d} t$ を次式で表す ${ }^{8), 13) 。 ~}$

$$
\mathrm{d} P_{X_{p}} / \mathrm{d} t=K_{u} \cdot\left(P_{X_{P m}}-P_{X_{p}}\right)
$$

ここで, $K_{u}$ は脱リン性微生物によるリンの摂取速度定 数である。 $P_{X p m}$ は脱リン性微生物の最大のリン含有率 であり，その值として 0.15kgP·kgMLSS ${ }^{-1}$ とする ${ }^{11)} 。$ $K_{u}$ は体内に蓄積している有機物濃度の関数であり, 蓄 積した有機物濃度 $\left(S_{X_{p}}\right)$ に対し次式の Monod 型で表 現できると仮定する。

$$
K_{u}=K_{u m} \cdot S_{X p} /\left(K_{S X}+S_{X_{p}}\right)
$$

ただし， $K_{u m}$ は $S_{X_{p}}$ が制限しない時のリンの摂取速度 定数であり， $S_{X_{p}}$ は脱リン性微生物の体内に蓄積した 有機物の量, $K_{S X}$ は飽和定数である。

一方, 式(9)の様に微生物の増殖に伴らリンの摂取速 度は, 脱リン性微生物と非脱リン性微生物の増殖速度 の和に比例する。ここで, 脱リン性微生物の増殖速度 式は一般的に次の 1 次式で表現できる。

$$
\mathrm{d} X_{p} / \mathrm{d} t=\left(\mu_{p}-b_{p}\right) \cdot X_{p}
$$

ただし， $\mu_{p}$ は脱リン性微生物の比増殖速度定数であ り, $b_{p}$ は脱リン性微生物の死隇速度定数である。 $\mu_{p}$ は 蓄積有機物扣よび液中のリンの濃度の関数とし, 一般 的に次式の Monod 型で表す。

$$
\mu_{p}=\mu_{p m} \cdot\left\{S_{X_{p}} /\left(K_{S X}+S_{X_{p}}\right)\right\} \cdot\left\{P /\left(K_{p}+P\right)\right\}
$$

ただし， $\mu_{p m}$ は脱リン性微生物の最大の比増殖速度 定数である。 $P$ は液中のリンの濃度であり, $K_{p}$ は液中 のリン濃度の飽和定数である。

一方, 非脱リン性微生物の増殖式も脱リン性微生物 と同様に表現すると，

$$
\mathrm{d} X_{n} / \mathrm{d} t=\left(\mu_{n}-b_{n}\right) \cdot X_{n}
$$
ただし，

$$
\mu_{n}=\mu_{n m} \cdot\left\{S_{X_{n}} /\left(K_{S X}+S_{X_{n}}\right)\right\} \cdot\left\{P /\left(K_{p}+P\right)\right\}
$$
ここで, $\mu_{n}$ は非脱りン性微生物の比増殖速度定数であ り, $b_{n}$ は非脱リン性微生物の死隇速度定数である。 $S_{X_{n}}$ は非脱リン性微生物の体内に蓄積した有機物の量, $\mu_{n m}$ は脱リン性微生物の最大の比増殖速度定数であ る。

式(9)に式(10)〜(15)を代入乙, 解を求めると好気状態に 和ける槽内和よび微生物体内でのリンの挙動が推定で きる。

以上に述べたリンに関する基礎式を Table 1 にまと めた。Table 1 の左辺は嫌気状態, 右辺は好気状態に拉 ける系でのリンの物質収支式执よび速度式である。 
Table 1 Basic equations for phosphorus during a cycle period.

\begin{tabular}{|c|c|c|c|}
\hline & & Anaerobic Condition & Aerobic Condition \\
\hline \multicolumn{4}{|c|}{ mass balance } \\
\hline$P$ & \multicolumn{2}{|r|}{$d P / d t=-X_{P} \cdot d P x_{P} / d t$} & $-d P / d t=X_{P} \cdot d P x_{P} / d t+P x_{P} \cdot d X_{P} / d t+P x_{n} \cdot d X_{n} / d t$ \\
\hline \multicolumn{4}{|c|}{ kinetic reaction } \\
\hline \multirow[t]{2}{*}{$\mathrm{Px}$} & $\mathrm{p}$ & $\begin{array}{r}d P x_{P} / d t=\left(d P x_{P} / d t\right)_{1}+\left(d P x_{D} / d t\right)_{2} \\
=-K_{r s m} \cdot(S-S a) /\{K s+(S-S a)\} \cdot P x_{p} \\
-K_{r \theta} \cdot\left(P x_{P}-P e_{p}\right) /\left(K p x+\left(P x_{D}-P e_{P}\right)\right\}\end{array}$ & $d P x_{P} / d t=K_{u m} \cdot\left\{S x_{p} /\left(K s x+S x_{P}\right)\right\} \cdot\left(P x_{P m}-P x_{P}\right)$ \\
\hline & $\mathrm{n}$ & & \\
\hline \multirow[t]{2}{*}{$x$} & $p$ & & $\begin{aligned} \mathrm{d} X_{p} / d t & =\left(\mu_{P}-b_{P}\right) \cdot X_{P} \\
\mu_{\mathrm{P}} & =\mu_{\mathrm{mP}} \cdot\left\{S X_{P} /\left(K s x+S X_{P}\right)\right\} \cdot\{P /(K p+P)\}\end{aligned}$ \\
\hline & $\mathrm{n}$ & & $\begin{aligned} \mathrm{d} X_{n} / d t & =\left(\mu_{n}-b_{n}\right) \cdot X_{n} \\
\mu_{n} & =\mu_{m n} \cdot\left\{S X_{n} /\left(K s X+S X_{n}\right)\right\} \cdot\{P /(K p+P)\}\end{aligned}$ \\
\hline
\end{tabular}

p:phosphorus accumulating biomass

$n$ :phosphorus non-accumulating biomass

\section{3 有機物の挙動特性の定式化}

\subsection{1 傔気状態での有機物の摄取，分解速度}

嫌気状態に扔ける槽内の有機物は全微生物によって 摂取され, 体内に蓄積, 分解される。槽内での有機物 の物質収支式は次式で表現できる。

$$
-\mathrm{d} S / \mathrm{d} t=\left\{X_{p} \cdot \mathrm{d} S_{X_{p}} / \mathrm{d} t+X_{n} \cdot \mathrm{d} S_{X_{n}} / \mathrm{d} t / \alpha \quad(16)\right.
$$

ただし， $\alpha$ は摂取された有機物の微生物体内への転換 係数である。

槽内の有機物の減少速度は共存する脱 リン性微生物 と非脱リン性微生物による摂取速度の和であり, その 際の有機物の摂取速度は摄取可能な有機物の濃度に 1 次で比例すると仮定し，次式で表す。

$$
-\mathrm{d} S / \mathrm{d} t=-\left\{k_{1} \cdot\left(S-S_{a}\right) \cdot X_{p}+k_{2} \cdot\left(S-S_{a}\right) \cdot X_{n}\right.
$$

ここで， $k_{1}$ は脱リン性微生物による有機物の摄取速度 定数, $k_{2}$ は非脱りン性微生物による有機物の摂取速度 定数である。

一方, 摄取された有機物は脱リン性微生物と非脱り ン性微生物の体内に蓄積, 分解される。前節で述べた ように，脱リン性微生物が生命体の内生的な維持のた めにリン酸を利用するのに対して, 非脱リン性微生物 は蓄積した有機物を利用している。これを考慮した微 生物体内への有機物の蓄積速度は, 微生物量が不変と すると次式となる。

$$
\begin{aligned}
& \mathrm{d} S_{X} / \mathrm{d} t=\mathrm{d} S_{X_{p}} / \mathrm{d} t+\mathrm{d} S_{X_{n}} / \mathrm{d} t \\
& \mathrm{~d} S_{X_{p}} / \mathrm{d} t=\alpha \cdot k_{1} \cdot\left(S-S_{a}\right) \\
& \mathrm{d} S_{X_{n}} / \mathrm{d} t=\alpha \cdot k_{2} \cdot\left(S-S_{a}\right)-k_{3} \cdot S_{X_{n}}
\end{aligned}
$$

ただし， $S_{X}$ は単位重量当りの微生物体内に蓄積され た有機物量, $k_{3}$ は非脱リン性微生物の内生的な生命維 持による蓄積有機物の分解速度定数である。
式(16) と式(18)に式(19)～(20)を代入し，初期条件を与兄て 解を求めると, 嫌気状態の槽内打よび微生物体内の有 機物の濃度変化が推定できる。

ここで初期条件は, 対象とした系の実験条件に対応 して与兄られる。すなわち, 有機物の濃度の初期条件 は

$$
t=0, S=S_{0}, S_{X}=S_{X_{0}}
$$

で与えられる。

ここで， $S_{0}$ は基質溶液を投入した直後の液中の有機 物の濃度である。 $S_{X_{0}}$ は 1 サイクルの間に, 好気状態で 分解された後に体内に残存している有機物の量と, 微 生物による吸着が生じた後に体内に蓄積された有機物 の量の和である。ただし， $S_{0}$ は微生物による吸着が生 じた後の有機物の平衡濃度で, この平衡関係は Freundlich 式によって表現できる11)。

$$
q_{0}=\mathrm{k} \cdot\left(S_{0}\right)^{1 / \mathrm{n}}
$$

また， $S_{X_{0}}$ と $q_{0}$ との関係は次式のように与兄られる。

$$
S_{X_{0}}=S_{X_{r}}+\alpha \cdot q_{0}
$$

ただし， $q_{0}$ は微生物の単位重量当りの有機物の吸着 量, $\mathrm{k}, \mathrm{n}$ は Freundlich 定数であり, その值としてそれ ぞれ $4.5 \times 10^{-3}$ 抢よび1.35とする11) $S_{X_{r}}$ は 1 サイクル の間に好気状態で分解された後に体内に残存している 有機物の量である。

微生物体内に蓄積された有機物が好気状態で分解さ れ, $S_{X_{r}} \ll \alpha \cdot q_{0}$ の場合は, $S_{X_{r}}$ を無視すると, 式(23)は次 の式(24)で近似できる。

$$
S_{X_{0}}=\alpha \cdot q_{0}
$$

\subsection{2 好気状態での有機物の摄取, 分解速度}

好気状態での微生物による槽内からの有機物の摂取 速度と微生物体内での有機物の分解速度は, 脱リン性 
Table 2 Constants used for the simulation.

\begin{tabular}{|c|c|c|c|c|}
\hline constant & & value & unit & ref. \\
\hline $\mathrm{Krs}_{\mathrm{m}}$ & & 0.15 & $h^{-1}$ & 11) \\
\hline Kre & 1.1 & $\times 10^{-3}$ & $h^{-1}$ & 13) \\
\hline $\mathrm{Ks}$ & 50 & $\times 10^{-3}$ & $\mathrm{~kg} \cdot \mathrm{m}^{-3}$ & 11) \\
\hline $\mathrm{Kpx}$ & 14 & $\times 10^{-3}$ & $\mathrm{~kg} \cdot \mathrm{kg}^{-1}$ & 13) \\
\hline $\mathrm{k}_{1}$ & 2. 0 & $\times 10^{-4}$ & $\mathrm{~m}^{3} \cdot \mathrm{kg}^{-1} \cdot \mathrm{h}^{-1}$ & 11) \\
\hline $\mathrm{k}_{2}$ & 6.9 & $\times 10^{-4}$ & $\mathrm{~m}^{3} \cdot \mathrm{kg}^{-1} \cdot \mathrm{h}^{-1}$ & 11) \\
\hline $\mathrm{k}$ & 4.5 & $\times 10^{-3}$ & {$[-]$} & 11) \\
\hline $\mathrm{n}$ & & 1. 35 & {$[-]$} & 11) \\
\hline$\alpha$ & & 0.45 & {$[-]$} & 16) \\
\hline $\mathrm{Ku} \mathrm{m}_{\mathrm{m}}$ & & 0.02 & $h^{-1}$ & 13) \\
\hline K sx & 1.5 & $\times 10^{-3}$ & $\mathrm{~kg} \cdot \mathrm{kg}^{-1}$ & as sumed \\
\hline Kр & 4 & $\times 10^{-4}$ & $\mathrm{~kg} \cdot \mathrm{m}^{-3}$ & $15)$ \\
\hline$\mu_{\mathrm{m}}$ & & 0.04 & $h^{-1}$ & 18) \\
\hline b & 3.2 & $\times 10^{-3}$ & $h^{-1}$ & 14) \\
\hline $\mathrm{k}_{4}$ & 10 & $\times 10^{-4}$ & $\mathrm{~m}^{3} \cdot \mathrm{kg}^{-1} \cdot \mathrm{h}^{-1}$ & 12) \\
\hline$k_{5}$ & & 0.55 & $h^{-1}$ & 16) \\
\hline
\end{tabular}

微生物も非脱リン性微生物も同一であると仮定し, 次 式を用いた。

$$
\begin{aligned}
& \mathrm{d} S / \mathrm{d} t=-k_{4} \cdot\left(S-S_{e}\right) \cdot X \\
& \mathrm{~d} S_{X} / \mathrm{d} t=\alpha \cdot k_{4} \cdot\left(S-S_{e}\right)-k_{5} \cdot S_{X}
\end{aligned}
$$

ただし， $k_{4}$ は好気状態での微生物による槽内からの有 機物の摂取速度定数, $k_{5}$ は微生物体内に蓄積された有 機物の分解速度定数, $S_{e}$ は生分解しにくい有機物の濃 度である。

式(26)に打いて, 微生物体内に蓄積された有機物の分 解速度は, 好気状態で有機物が蓄積される速度とリン の過剩摂取扔よび増殖に伴って蓄積有機物を分解する 速度の差である。式(25)と(26)に対して解を求めると, 好 気状態での反応槽内拉よび微生物内の有機物の挙動に ついて推定できる。

以上の連立方程式の解を求めると, 嫌気・好気状態 に抢けるリン括よび有機物の濃度変化の推定ができ る。

\section{3. パラメータの決定}

本モデルに损いて使用したパラメータの值を Table 2 に示した。各パラメータについては, その多くのもの は著者らの既報告 ${ }^{11,13)}$ の実験から求めた值之文献

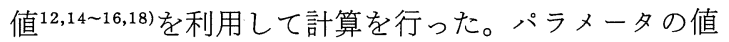
は温度293K での值である。リンの放出括よび摂取速 度は微生物体内のリンの含有率に基づいて得られたも のである。また，嫌気状態に抢ける脱リン性微生物に よる有機物の摂取速度は, 全微生物中のリン含有率が $0.15 \mathrm{kgP} \cdot \mathrm{kgMLSS}^{-1}$ でリンの放出が生じるときに, 摂 取された有機物の濃度の変化から決定したものであ る。非脱リン性微生物による有機物の摂取速度は, 全 微生物中のリン含有率が $0.02 \mathrm{kgP} \cdot \mathrm{kgMLSS}^{-1}$ でリン

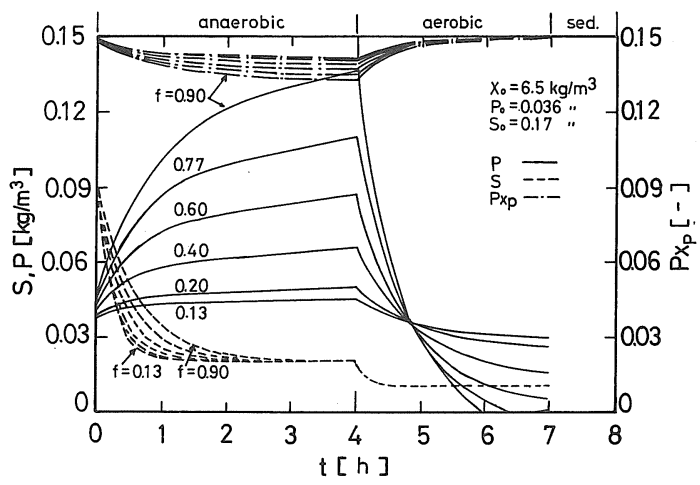

Fig. 2 Effect of $\mathrm{f}$ on changes of phosphorus (P) and organic carbon (S) concentrations.

の放出が生じないときに，摂取された有機物の濃度の 変化から決定したものである。一方, 嫌気状態での速 度定数の中で, 非脱リン性微生物の生命体の内生的な 維持のために蓄積された有機物の分解速度は, 蓄積速 度に比べて無視できる程度小さいと仮定し， $k_{3}=0$ を 用いて計算を行った。また，好気状態で蓄積された有 機物の分解速度定数 $\left(k_{5}\right)$ の值は Bordacs ${ }^{16)}$ による 実験結果で求めた值を用いて計算を行った。るた，KSX の值は実測值とよく一致している值を繰り返し計算に より決定した。最大の比增速度定数 $\left(\mu_{m}\right)$ 执よび死隇速 度定数 $(b)$ は脱リン性微生物子非脱リン性微生物も同 じ值を用いて計算を行った。

\section{4. 結果と考察}

本モデルを用いて動的定常状態における嫌気・好気 繰り返しの 1 サイクル（8時間）の間に, 脱リン性微 生物の全微生物中の存在の割合 (f), 有機物の濃度, 微 生物の濃度, 比増殖速度などの変化によって, 槽内と 微生物体内のリン抢よび有機物の挙動がどのような影 響を受けるかについて検討を加えた。ここでの動的定 常状態とは，サイクルを繰り返し循環するときに， 1 サイクルの間の微生物内のリンおよび有機物が変化す ることによって槽内のリン濃度の増加および減少が一 定に繰り返す状態を意味する。

\section{1 脱リン性微生物の存在の割合(f)の影響}

槽内のリン拉よび有機物の濃度と脱リン性微生物内 のリン含有率の変化に及ぼす $\mathrm{f}$ の影響について推算し た結果を Fig. 2 に示す。初期条件として, 全微生物の 濃度 $(X)=6.5 \mathrm{~kg} \cdot \mathrm{m}^{-3}$, リンの濃度 $(P)=0.036 \mathrm{~kg}$ • $\mathrm{m}^{-3}$, そして有機物の濃度 $(S)=0.17 \mathrm{kgTOC} \cdot \mathrm{m}^{-3}$ の值 を用いて推算した。1サイクルの間の嫌気・好気状態 に抢ける槽内のリン濃度は $\mathrm{f}$ の変化と共に大きく変化 している。この推算では, 初期のリン濃度, $P_{0}=0.036$ 


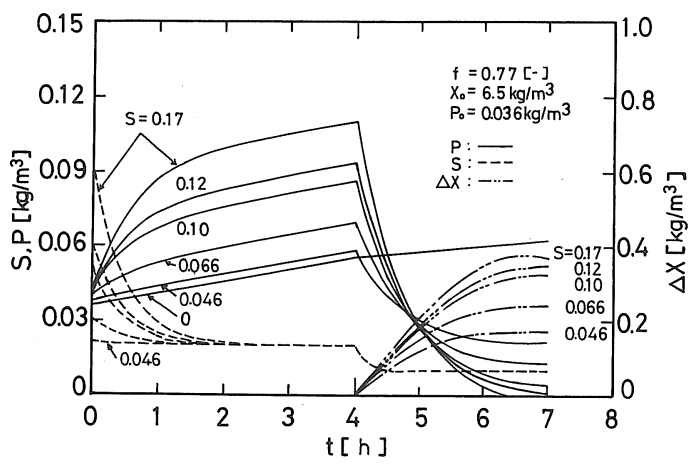

Fig. 3 Effect of influent organic substrate $\left(\mathrm{S}_{0}\right)$ on changes of phosphorus and organic substrate concentrations.

$\mathrm{kg} \cdot \mathrm{m}^{-3}$ では $\mathrm{f}=0.65$ 以上で微生物によって槽内から リンが完全に摂取されている。辞大きくなるととも に，微生物からのリン放出・摂取速度が速くなってく る。この現象は嫌気状態で脱リン性微生物の有機物の 蓄積に伴らリン放出が大きく生じ，その結果，好気状 態で脱リン性微生物による過剰リンの摂取と増殖量が 多くなり，それに伴い槽内のリン濃度の減少速度が速 くなるためである。逆に，fが小さくなるほど，嫌気・ 好気状態で槽内のリン濃度の変化は少なくなってい る。この場合には，嫌気状態での有機物の利用が非脱 リン性微生物の方が脱リン性微生物に比べて多くな り，脱リン性微生物のリン放出反応よりも非脱リン性 微生物の生化学反応が進んでいるためであると考壳ら れる。従って，この脱リンプロセス系で $\mathrm{f}$ の值は重要な 因子であり，特に，嫌気状態で槽内に微生物により摂 取可能な有機物が存在している間は，リンの放出につ いて $\mathrm{f} か ゙$ 主たる影響を与える因子であることが解っ た。

\section{2 有機物および微生物の濃度の影響}

Fig.3 は 1 サイクルの間のリンの挙動に及ぼす初期 有機物の濃度の影響について計算した結果である。本 計算では $\mathrm{f}=0.77, P_{0}=0.036 \mathrm{~kg} \cdot \mathrm{m}^{-3}$ で一定とし, 有機 物の濃度を $0 \sim 0.17 \mathrm{kgTOC} \cdot \mathrm{m}^{-3}$ の範囲で変化させて 推算を行った。リンの濃度変化は槽内の有機物の存在 によって影響を受ける。嫌気状態でのリンの放出速度 は，初期段階に拈ける有機物の濃度に大きく影響を受 けることがわかる。たと壳ば，初期のリン濃度が $P_{0}=$ $0.036 \mathrm{~kg} \cdot \mathrm{m}^{-3}$ の場合，1サイクルの間にそれを除去す るには最小限の有機物濃度として0.12kgTOC・m $\mathrm{m}^{-3}$ が 必要であることを表している。

一方，槽内に有機物が存在しない場合にも，嫌気状 態で槽内のリン濃度は増加しているが，これは本モデ ルで提案した脱リン性微生物の内生的な維持のための

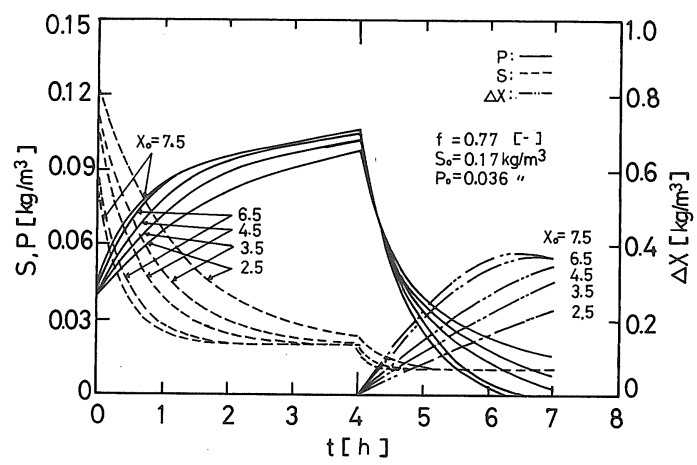

Fig. 4 Effect of biomass concentration on changes of phosphorus and organic substrate concentrations.

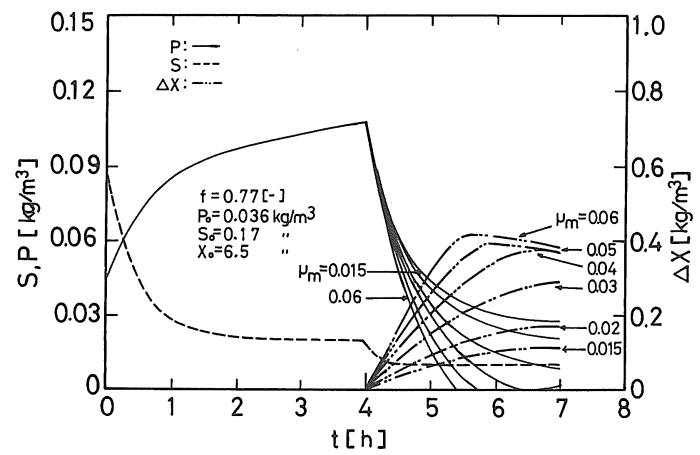

Fig. 5 Effect of $\mu_{m}$ on change of phosphorus and organic subtsrate concentration.

放出したリンであり，さらに好気状態での槽内のリン 濃度の増加は微生物の自己分解により生じているもの であると考觉られる。

Fig. 4 は, 初期の有機物濃度, リン濃度およびfを一 定として，槽内のリン濃度执よび有機物濃度の変化に 扣よぼす全微生物の濃度の影響についてシミュレー ションした結果の一例である。全微生物の濃度が高く なっても, 嫌気状態での槽内のリン濃度の変化には影 響をあまり与えていない。すなわち，槽内の全微生物 濃度は, 脱リン性微生物の全微生物体中の存在の割合 (f)や有機物の濃度のよ5な因子に比べて槽内のリン の濃度変化にさほど大さく影響を与えていないことを

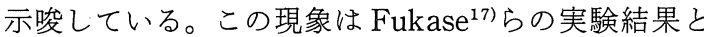
一致している。これは，微生物当りの有機物の負荷の 差により生じるものであると判断される。従って，槽 内のリン濃度変化については, 全微生物濃度よりも $\mathrm{f}$ と嫌気状態での有機物濃度がより重要な影響因子であ ることが解った。 


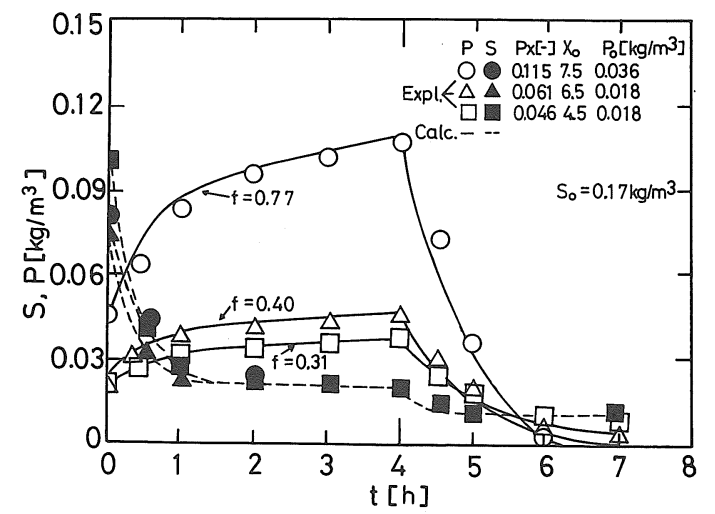

Fig. 6 Comparison of experimental and simulation results.

\section{3 微生物の最大の比増殖速度 $\left(\mu_{m}\right)$ の影響}

Fig.5はリンの挙動に及ぼす $\mu_{m}$ の影響について計 算した結果である。初期条件として, 全微生物の濃度 $\left(X_{0}\right)=6.5 \mathrm{kgMLSS} \cdot \mathrm{m}^{-3}$, リンの濃度 $\left(P_{0}\right)=0.036$ $\mathrm{kgP} \cdot \mathrm{m}^{-3}$, そして有機物の濃度 $\left(S_{0}\right)=0.17 \mathrm{kgTOC}$ $\mathrm{m}^{-3}$ の值を用いて推算した。また，ここで利用した $\mu_{m}$ の值は脱リン性微生物と非脱リン性微生物ともに同一 の值であると仮定し，0.015 0.06h-1 の範囲で計算を 行った。

好気状態に打けるリンの摂取は, $\mu_{m}$ に大きく影響を 受けていることがわかる。従って, 脱リン性微生物の $\mu_{m}$ を大きくすることは脱リンにおいての重要な課題 の一つである。本計算に拉いて, $\mu_{m}$ の值が $0.04 \mathrm{~h}^{-1}$ 以上 である場合, 増加した微生物の濃度 $(\Delta X)$ は約 $0.4 \mathrm{~kg}$ $\mathrm{MLSS} \cdot \mathrm{m}^{-3}$ となり，この值を基にして増殖収率 $(Y)$ を 計算すると $4.0 〜 4.5 \mathrm{kgMLSS} \cdot \mathrm{kgS} \mathrm{S}_{X}{ }^{-1}$ になる。しかし ながら, 実際の増殖収率は3.0〜 $3.5 \mathrm{kgMLSS} ・ \mathrm{kgS}_{X}{ }^{-1}$ 程度であり，この值を基にして計算すると増加した微 生物の濃度は0.3kgMLSS・ $\mathrm{m}^{-3}$ となる。この計算值と 実測值との差の原因としては, 式(26)の $k_{5}$ と $\mu_{m}$ の関係 が完全にリンクされていないからであると考学られ る。つまり, 最大の比増殖速度 $\left(\mu_{m}\right)$ の増加とともに微 生物体内に蓄積された有機物の分解速度定数 $\left(k_{5}\right)$ b増 加すべきであるが，本計算では $k_{5}$ の值を一定としたか らである。この面については，実験を通した定量的な 検討が要求されている。

一方，前節でのリン濃度の変化計算に和ける $\mu_{m}$ の

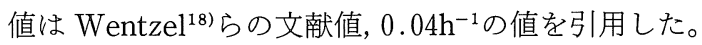

\section{4 モデル妥当性の検討}

前述したモデルの妥当性を確認するために, 動的定 常状態での計算値と実験值とを比較した結果を Fig.6 に示した。図の中で, 実線は計算值, 記号 $(\bigcirc, \triangle$,

口) は実験值を示す。槽内のリン濃度, 有機物濃度の
変化はいずれも計算值と実験值がほぼ一致している。 しかしながら，好気状態での計算值は実測值より若干 低い值を示しているが，この原因としては，本モデル に沶いて，嫌気状態で非脱リン性微生物による蓄積有 機物の分解を無視しているためであると考古られる。 この点については非脱リン性微生物による分解速度を 考慮したモデル化が今後の課題である。しかしながら， 以上のように槽内のリン濃度と有機物濃度の変化に関 して，好気状態で計算值と実験值とに多少相違がある もののほぼ良好な一致が見られ，本モデルは妥当なも のであると考えられる。

\section{5. 結論}

本研究では, 嫌気・好気法による生物学的脱リン過程 に関して簡単なモデル化を行い, システム全体でのリ ンおよび有機物の濃度の変化を推定した。本モデルで は，活性污泥中は微生物体内のリン含有率を基にして 脱リン性と非脱リン性微生物の二相から構成されてい るものとし，1サイクルの間のリン执よび有機物の濃 度の変化の特性について検討を加えた。1サイクルの 間にリンの濃度の変化に及ぼす因子を検討した結果, 槽内での脱リン性微生物の存在の割合, 嫌気状態の初 期段階に扣ける有機物の濃度がリンの挙動に大きく影 響を与えることが解った。さらに，実験結果と比較検 討した結果，本モデルによりほぼ正確にその濃度変化 の特性を表し得ることが確認された。

しかし, 本モデルの今後の課題として, 非脱リン性 微生物体内の有機物の蓄積と分解に対しても正確に適 用しらるモデルの提案が挙げられる。

（原稿受理 1990年 4 月20日）

\section{記 号}

$\mathrm{f}$ : 全微生物中の脱リン性微生物の存在割合, 一

$\mathrm{k}$ : Freundlich 定数, 一

$k_{1,2,4}:$ 有機物の摂取速度定数, $\mathrm{m}^{3} \cdot \mathrm{kg}^{-1} \cdot \mathrm{h}^{-1}$

$k_{3,5}$ : 蓄積有機物の分解速度定数, $\mathrm{h}^{-1}$

$K_{r s} \quad$ : リンの放出速度定数, $\mathrm{h}^{-1}$

$K_{r e} \quad$ : リンの放出速度定数, $\mathrm{h}^{-1}$

$K_{u} \quad$ : リンの摄取速度定数, $\mathrm{h}^{-1}$

$K_{p X}$ : リン含有率の飽和定数, $\mathrm{kg} \cdot \mathrm{kg}^{-1}$

$K_{p} \quad$ : リン濃度の飽和定数, $\mathrm{kg} \cdot \mathrm{m}^{-3}$

$K_{S} \quad$ : 有機物濃度の飽和定数, $\mathrm{kg} \cdot \mathrm{m}^{-3}$

$K_{S X} \quad$ : 蓄積有機物濃度の飽和定数, $\mathrm{kg} \cdot \mathrm{m}^{-3}$

$\mathrm{n}$ : Freundlich 定数, -

$P \quad:$ リンの濃度, $\mathrm{kg} \cdot \mathrm{m}^{-3}$

$P_{X} \quad$ : 微生物の単位重量当りリンの含有率, $\mathrm{kg} \cdot \mathrm{kg}^{-1}$

$P_{e} \quad$ : 微生物の単位重量当り必須リンの含有率, $\mathrm{kg} \cdot \mathrm{kg}^{-1}$

$q_{0}$ : 微生物の単位重量当りの有機物の吸着量, $\mathrm{kg} \cdot \mathrm{kg}^{-1}$ 


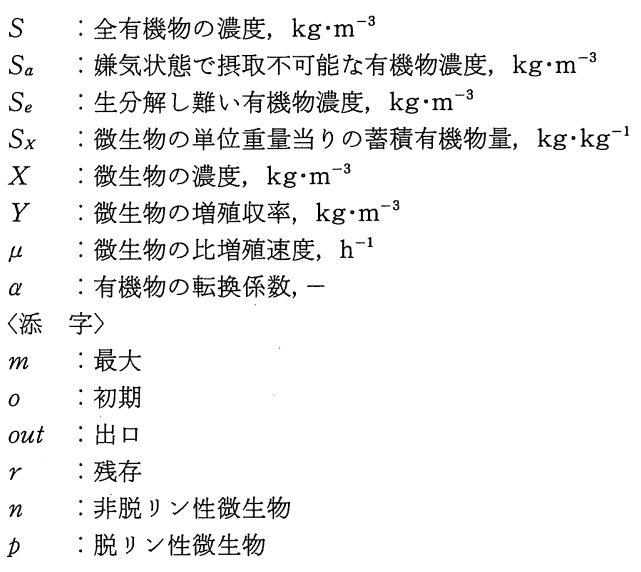

\section{引用 文 献}

1) Brah, G.S. and Tollefson, E.L. (1975) The luxury uptake phenomenon for removal of phosphates from municipal wastewater, Water Research, 9, 71-77.

2 ) Nicholl, H.A. and Osborn, D.W. (1979) Bacterial stress: Prerequisite for biological removal of phosphorus, $J$. Water Pollution Control Federation, 51, 557-569.

3 ) Lotter, L.H. and Dubery, I.A. (1987) Metabolic control in polyphosphates-accumulating bacteria and its role in enhanced biological phosphate removal, Proc. of an IAWPRC, Italy, pp7-14.

4) Florentz, M., Granger, P. and Hartemann, P. (1984) Use of ${ }^{31} \mathrm{P}$ nuclear magnetic responence spectroscopy and electron microscopy to study phosphorus metabolism of microorganisms from wastewater, Applied and Environmental Microbiology, 47, 519-525.

5 ) Mino, T., Kawakami, T. and Matsuo, T. (1984) Location of phosphorus in activated sludge and function of intracellular polyphosphates in biological phosphorus removal process, Water Science and Technology, 23, 93-106.

6) Arun, V., Mino, T. and Matsuo, T. (1988) Biological of mechanism of acetate uptake mediated by carbohydrate consumption in excess phosphorus removal systems, Water
Research, 22, 565-570.

7 ) Comeau, Y., Hall, K.J., Hancock, R.E.W. and Olham, W.J (1986) Biochemical model for enhanced biological phosphorus removal, Water Research, 20, 1511-1521.

8 ) Tsuno, H., Somiya, I. and Matsumoto, M. (1987) A Kinetic model for biological phosphorus removal incorporating intracellular organics and phosphorus pools, Proc. of an IAWPRC, Italy, pp99-110.

9) Harold, F.M (1966) Inorganic polyphosphates in biology : structure, metabolism, and function, Bacteriol. Review, 30, 772-795.

10) Tracy, K.D. and Flammino, A. (1987) Biochemistry and energics of biological phosphorus removal, Proc. of an IAWPRC, Italy, 6615-26.

11）鈴木基之，尹照熙（1990）生物学的脱リンに拈ける嫌気状態 で微生物中のリンおよび有機物の挙動, 化学工学論文集, 16 , 376-383.

12) Grady, C.P.L. and H.C. Lim: "Biological Wastewater Treatment", Dekker, New York and Basel (1980).

13) Yoon, C.H. and Suzuki, M., Kinetics of biological phosphorus behavior in sequential batch reactor under anaerobic/aerobic conditions, J. Chemical Engineering, Japan, (in press).

14) Benfield, L. and Molz, F. (1984) A Model for the activated sludge process which considers wastewaters characteristics, floc behavior, and microbial population, Biotechnology and Bioengineering, 26, 352-361.

15) Wu, Y.C. and Okrutny, M.S. (1982) The role of phosphorus in activated sludge, Water Pollution Control, 81, 558 $-565$.

16) Bordacs, K. and S.C. Chiesa (1989) Carbon flow patterns in enhanced biological phosphorus accumulating activated sludge cultures, Water Science and Technology, 21, 387.

17) Fukase, T., Shibata, M. and Miyajj, Y. (1984) The role of an anaerobic stage on biological phosphorus removal, Water Science and Technology, 17, 69-80.

18) Wentzel,M.C., Dold, P.L., Loewenthal, R. E., Ekama, G.A. and Marais, G.v.R. (1987) Experimental towards establishing the kinetics of biological phosphorus removal, Proc. of an IAWPRC, Italy, pp79-97. 


\section{論文要旨}

\section{不織布担体の好気性微生物付着機構に関する研究}

\section{油科 嘉則* 長谷川 潤*}

* 千代田化工建設株式会社研究開発センター

〈水質污濁研究 Vol. 13 No.7 (1990) pp. 431 440〉

生物膜法による排水処理において微生物担体として合成樹脂，セラミック，砂などが従来より用いられてき た。反応槽中の微生物濃度は生物処理性能に関与するため微生物担体はその比表面積を増加させることに重点 が置かれてきた。微小粒状担体を用いた流動床法はその一例である。合成樹脂不織布は糸表面への微生物付着 および繊維が織りなす立体空間での微生物の増殖により高効率な微生物担体と考えられる。しかしながら，好 気性担体としての不織布の応用に関する報告は少ない。そこで不織布の初期沪過テスト，槽内での初期微生物 付着テストおよび微生物増殖テストを実施し，不織布への好気性微生物付着機構を明らかにするために実験的 検討を行った。その結果，付着微生物濃度に関して比表面積よりはむしろ不織布の目開き間隔に至適範囲が存 在することが判った。また浮遊微生物と付着微生物の組成の差異が動力学定数に影響を与えた。

\section{生物学的脱リン過程の二相生物モデルによるシミュレーション}

\section{尹照熙* 鈴木 基之*}

* 東京大学生産技術研究所

〈水質污濁研究 Vol. 13 No.7 (1990) pp. 441 448〉

嫌気・好気繰り返し法による生物学的脱リンにおける 1 サイクル中のリンおよび有機物の濃度変化を記述す るために，污泥がその脱リン特性に基づき，脱リン性微生物と非脱リン性微生物の二相から構成するものとし， 有機物の濃度影響を考慮したモデルを提案した。

1 サイクルの間のリンの放出，摂取挙動は脱リン性微生物，嫌気状態での投入有機物などに大きく影響され る。また，槽内の有機物は嫌気状態で微生物によりほほ攝取されている。実験による濃度変化の測定結果は， 簡単なモデルにより，ほぼ正確に表し得ることが確認された。 